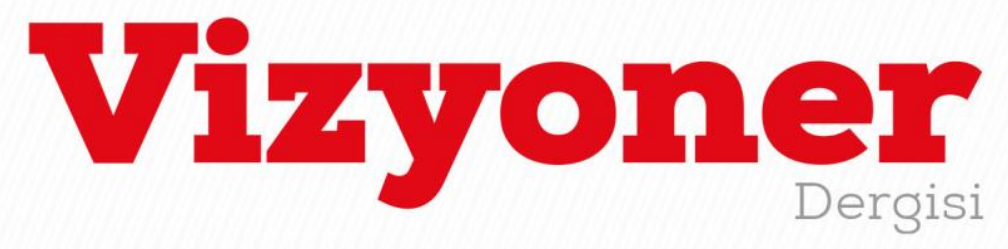

Süleyman Demirel Üniversitesi Vizyoner Dergisi, Yıl: 2021, Cilt: 12, Sayı: 30, 381-392.

Süleyman Demirel University Visionary Journal, Year: 2021, Volume: 12, No: 30, 381-392.

\title{
INTERNATIONAL TRADE OF CULTURAL PRODUCTS AND ECONOMIC GROWTH: A PANEL DATA ANALYSIS
}

\section{KÜLTÜREL ÜRÜNLERIN ULUSLARARASI TICARETI VE EKONOMIK BÜYÜME: PANEL VERI ANALIZI}

\author{
Assoc. Prof. Dr. Fatih Cemil ÖZBUĞDAY ${ }^{1}$ \\ Res. Asst. Dr. Önder ÖZGÜR²
}

\begin{abstract}
The potential of international trade of cultural products in fostering economic growth has been neglected in the empirical economics literature. The study explores the relationship between international trade of cultural products and gross domestic product (GDP) per capita in 85 countries between 2004-2017 using the Pedroni cointegration test and Swamy (1970)'s random coefficient model. The results show that although the trade balance of cultural products does not affect economic growth, the volume of international trade in cultural products has a statistically significant and positive impact on GDP per capita. These findings indicate that policymakers should not require protective steps against the imports of cultural goods or services and the call of the 2005 UNESCO Convention on the Protection and Promotion of the Diversity of Cultural Expressions to developed economies to open their markets is an appropriate suggestion.
\end{abstract}

Keywords: Cultural Products, Cultural Industries, International Trade, Economic Growth, UNESCO.

JEL Classification Codes: B17, C23, Z19.

ÖZ

Kültürel ürünlerin ticaretinin ekonomik büyümeyi teşvik etme potansiyeli iktisat literatüründe ihmal edilmiştir. Bu çalışma kültürel ürünlerin uluslararası ticareti ile gayrisafi yurtiçi hasıla (GSYİH) arasındaki ilişkiyi 85 ülke için 2004-2017 döneminde Pedroni eşbütünleşme testi ve Swamy (1970) rassal katsatılı model kullanarak analiz etmektedir. Çalışmanın sonuçları kültürel ürünlerin ticaret dengesinin GSYİH üzerinde istatistiksel olarak anlamlı olumlu bir etkisi bulunmadığını göstermektedir. Bu sonuçlar politika yapıcıların kültürel ürünlerin ithalatına yönelik kısıtlayıcı uygulamalara yer vermesine gerek olmadığını ve bu bağlamda 2005 UNESCO Kültürel İfadelerin Çeşitliliğinin Korunması ve Geliştirilmesi Sözleşmesi'nin gelişmiş ekonomilere pazarlarını açmaları çağrısının uygun bir öneri olduğunu göstermektedir.

Anahtar Kelimeler: Kültürel Ürünler, Kültürel Endüstriler, Uluslararası Ticaret, Ekonomik Büyüme, UNESCO.

JEL Sınıflandırma Kodları: B17, C23, Z19.

(D) Ankara Yıldırım Beyazıt University, Faculty of Political Sciences, Department of Economics, fcozbugday@ybu.edu.tr

(D) Ankara Yıldırım Beyazıt University, Faculty of Political Sciences, Department of Economics, onderozgr@ gmail.com

Makale Geliş Tarihi / Received : : 17.11.2020

Makale Kabul Tarihi / Accepted $\quad: 11.04 .2021$ 


\section{GENIȘLETILMIȘ ÖZET}

\section{Amaç ve Kapsam:}

Kültürel ürünlerin ticaretinin ekonomik büyüme üzerindeki etkisi bu ürünler uluslararası ticaretinin yaygınlaşmasıyla daha ilgi çeker hale gelmiştir. Öyle ki, 2005 yılında UNESCO tarafindan oluşturulan "Kültürel İfadelerin Çeşitliliğinin Korunması ve Geliştirilmesine İlişkin UNESCO Sözleşmesi” ile birlikte gelişmekte olan ülkelere kültürel ürünlerinin ticaretinin önündeki engellerin kaldırılması çağrısı yapılmış ve böylelikle bu ürünlerin ticareti daha yoğun bir hal almıştır. Bu sözleşmenin de etkisiyle kültürel ürünlerin dijitalleşmesinin de önü açılmış ve gelişen teknolojiyle birlikte dijital ürünler de ticareti yapılan kültürel ürünler olarak piyasaya çıkmaya başlamıştır. İktisat yazınında uluslararası ticaretin ekonomik büyüme üzerindeki etkileri sıklıkla analiz edilmiştir. Ancak uluslararası ticaretin bir türü olan kültürel ürün ticaretinin ekonomik aktivite üzerindeki etkisinin ampirik olarak sınanması göz ardı edilmiştir. Bu bağlamda bu çalışmanın amacı kültürel ürünlerin ticaretinin ekonomik büyüme üzerindeki etkisinin tespit edilmesine yönelik yazında yer alan ampirik çalışma boşluğunun giderilmesidir. Çalışmanın kapsamına veri uygunluğu göz önünde bulundurularak 85 ülke dahil edilmiştir. Ülkeler gelir gruplarına göre de sınıflandırılmıştır. Çalışma 20042017 yılları arasını kapsamaktadır.

\section{Yöntem:}

Çalışmanın ampirik bölümü iki kısımdan oluşmaktadır. İlk olarak kültürel ürünlerin ticareti ile ekonomik büyüme arasındaki eşbütünleşme ilişkisi Pedroni (1999, 2004) tarafindan ortaya konulan Pedroni eşbütünleşme testiyle sınanmıştır. Eşbütünleşme ilişkisi iki değişkenin uzun dönemde birlikte hareket edip etmediklerini ortaya koymaktadır. Böylelikle değişkenlerden birinin yaşayacağı bir şokun veya bu bağlamdaki bir politika değişikliğinin diğer değişken üzerinde de etkili olabileceğini ifade etmektedir. İkinci aşamada ise kültürel ürünlerin ticaretini temsilen kullanılan değişkenlerin ülkelerin kişi başına düşen Gayrisafi Yurtiçi Hasıla (GSYH) düzeyleri üzerindeki etkilerinin parametrik olarak tespit edilebilmesi amaciyla Swamy (1970) tarafindan literatüre kazandırılan rassal katsayılı model kullanılmıştır. Çalışmada yer alan ülkeler herhangi bir bölgesel veya ekonomik birlik ülkelerinden oluşmadığından, diğer bir ifadeyle çalışma örneklemi birbirinden farklı özellikler taşıyan ülkelerden oluştuğundan kültürel ticaretin ekonomik büyüme üzerindeki etkisinin ülkelere göre farklılıklar göstermesi beklenmektedir. Kullanılan bu yöntemler ülkeler arasındaki heterojenliklerin ortaya konulmasını sağamaya imkân tanımaktadır.

\section{Bulgular:}

Çalışmada kültürel ürünlerin ticareti ile ekonomik büyüme ilişkisi hem kültürel ürünlerin ticaret hacmi hem de kültürel ürün ticaret dengesi değişkenleri kullanılarak araştırılmıştır. Değişkenler arasındaki uzun dönem ilişkisinin sınandığı eşbütünleşme testi sonuçlarına göre 85 ülkeden oluşan panel veri seti setinde kültürel ürünlerin ticaret hacmi ile ekonomik büyüme arasında eşbütünleşme ilişkisi saptanamamıştır. Benzer şekilde kültürel ürünlerin ticaret hacmi ile ekonomik büyüme arasında da uzun dönemli eşbütünleşme ilişkisinin varlığı ampirik olarak reddedilmiştir. İkinci aşamada ise 85 ülkenin birbirinden farklı coğrafi, ekonomik ve kültürel özellikler taşımasından hareketle, kültürel ticaret dengesi ile kültürel ticaret hacminin 85 ülkede ekonomik büyüme üzerindeki katkısı tahmin edilmiştir. Rassal katsayılı model sonuçlarına göre kültürel ticaret hacminin ülkeler arasında ekonomik büyümeye katkı açısından homojen olmayan sonuçlar verdiği anlaşılmıştır. Veri setinde yer alan 85 ülkeden 13 tanesinde kültürel ticaret dengesinin ekonomik büyümeyi istatistiksel olarak anlamlı şekilde pozitif etkilediği görülmüştür. Diğer yandan kültürel ürün ticaret hacminin ekonomik büyüme üzerindeki etkisi de örneklemde yer alan ülkelerde homojen olmayan sonuçlar göstermektedir. Ticaret hacminin, ekonomik büyüme üzerindeki etkisinin ticaret dengesine göre daha anlamlı bir değişken olduğu görülmektedir. Şöyle ki, 85 ülkeden 43'ünde ticaret hacminin ekonomik büyüme üzerinde anlamlı etkisi olduğu tespit edilmiştir. Ayrıca bu ülkelerden 41 'inde kültürel ticaret ekonomik büyümeyi arttıran bir değişken olarak tespit edilmiştir. Rassal katsayılı model sonuçlarına göre kurulan iki modelde de kültürel ticaret ve ekonomik büyüme ilişkisinde ülkelerin milli gelir seviyelerine göre anlamlı farklılıklar bulunmadığını ifade etmek gerekir.

\section{Sonuç ve Tartışma:}

Ülkelerin kültürel ürün ticareti ile ekonomik büyümesi arasındaki ilişkinin analiz edildiği bu çalışmadan elde edilen sonuçlar birtakım politika çıkarımları yapılmasına olanak sağlamaktadır. İlk olarak şunu ifade etmek gerekir ki, veri setinde yer alan ülkelerde elde edilen farklı sonuçlar bir bütün olarak tek tip politika uygulamasının yararlı olmayabilecektir. Şöyle ki bazı ülkelerde kültürel ticaretin ekonomik büyüme üzerinde negatif etki yapması bu ülkelerin politika uygulaması bakımından diğer ülkelerden farklılaşmasını zorunlu kılmaktadır. Öte yandan, her ne kadar kültürel ticaret dengesinin ekonomik büyüme üzerindeki etkisi az sayılabilecek sayıdaki ülkede ekonomik büyümeyi anlamlı ve pozitif olarak etkiliyor olsa da kültürel ticaret hacminin ekonomik büyüme üzerinde anlamlı ve pozitif etki bıraktığı söylenebilir. Bu bağlamda Kültürel İfadelerin Çeşitliliğinin Korunması ve Geliştirilmesine İlişkin UNESCO Sözleşmesi” tarafından öngörüldüğü üzere ülkelerin kültürel ürün ticaretini geliştirmesi yolunda atılacak adımlar değerli ve anlamlıdır. Öte yandan, bu çalışmada kültürel ürün ticareti ile ekonomik büyüme üzerindeki ilişki analiz edilmiş olsa da ekonomik büyümeyi olumlu etkileyen kültürel ticaretin aynı zamanda yeni istihdam alanları açarak istihdamın gelişmesine katkı sunacağını söylemek gerekir. Hiç şüphesiz bu durumda özellikle gelişmekte olan ekonomilerin bir sorunu olarak karşımıza çıkan işsizliğin de azaltılmasına katkıda bulunulacaktır. 


\section{INTRODUCTION}

Culture contributes to economic activities in many ways. Local culture underpins cultural and creative industries. Producing goods and services has strong cultural elements. Traditional crafts are internationally valuable. An increasing number of "mass consumption" products (from cars to clothing) include cultural patterns. The value of consumer goods and services is closely related to their design and symbolic meaning: businesses are interested in cultural expressions and the processes of unique product development, communicate more effectively and explore alternative ways of being different. Local cultures provide content for movies, online goods, games and other communication channels. Furthermore, local cultural expressions and activities can play a key role for inclusive economic and social development. Cultural heritage, cultural industries and culture related issues can provide policy tools to generate income and jobs. Cultural diversity may be linked to economic development and be "productive" from an economic perspective (Duxbury, Hosagrahar and Pascual, 2016). The creation of all these "economic values" not only creates jobs and increases incomes at the local level, but also boosts economic growth and contributes to the vitality of local economies through the export of cultural products (Deloumeaux, 2016). This cultural contribution to economic growth is also a driver of sustainable development in many ways. Indeed, the culture's importance for sustainable development was picked out by the United Nations (UN) General Assembly in 2010 (UN, 2011), and its acknowledgment as a contributor to and enabler of sustainable development has become more dominant with the introduction of the 2030 agenda in 2015 for sustainable development.

The role of culture in economic growth has been particularly critical at a time of dramatic growth in the volume of international trade in cultural products. Following the 2005 UNESCO Convention on the Protection and Promotion of the Diversity of Cultural Expressions, developed countries were asked to open their markets to cultural produce from developing countries, the share of cultural property exports of developing countries in the world has begun to grow (UNESCO, 2015:121). Apart from the impact of the 2005 UNESCO Convention on the Protection and Promotion of the Diversity of Cultural Expressions, technological developments have also resulted in an increase in the volume of international trade flows of cultural property. The digitalisation or dematerialisation of some cultural products makes them available electronically to mass consumers worldwide. Following dematerialization, audio-visual services are increasingly becoming the most commercialized cultural services (Deloumeaux, 2016: 11).

The rise in the volume of international trade in cultural products has created new trade trends. As of 2010, China is the leading exporter of cultural goods surpassing the United States. Apart from China, India, Turkey and Malaysia became the major exporters of cultural goods between 2006 and 2016 (Deloumeaux, 2016: 27).

The increase in international trade in cultural property and the international slogans, which say that culture contributes to sustainable development, make us curious about the linkage between international trade in cultural products and economic growth. After examining the related documentation, we find that there is virtually no empirical effort to determine the contribution of international trade in cultural goods to economic growth. In the current paper, we aim to fulfill this gap. Specifically, we look at the relationship between international trade in cultural products and GDP per capita in 85 countries from 2004 to 2017. To this end, we use the Pedroni cointegration test offered by Pedroni $(1999,2004)$ and estimate the random coefficient model of Swamy (1970). These empirical specifications have distinct benefits in providing an insightful conclusion about the role cultural trade in economic growth for heterogenous panel datasets. The findings show that the volume of international cultural trade significantly affects per capita gross domestic product (GDP) in 43 of the 85 countries in the sample.

The structure of the paper is as follows: Part 2 provides a summary of the literature on the potential of cultural industries for economic value creation. Part 3 introduces the methodology used in the paper and describes the data. Part 4 displays empirical results. Finally, Part 5 discusses the findings, presents policy implications, and concludes.

\section{THE POTENTIAL OF CULTURAL INDUSTRIES FOR ECONOMIC VALUE CREATION}

The use or consumption of cultural services or products generates an economic impact that is largely ignored by economists and development agencies (Riofrio, 2014: 5). However, over the past decade, statistics, indicators, data and operational activities related to the cultural sector have highlighted that culture can be a strong driver of development, as well as social impacts; economics and environmental policies as a whole. Cultural heritage, cultural sectors, cultural infrastructure and sustainable cultural tourism can serve as a strategic instrument for 
income generation, particularly in growing countries with deep cultural heritage and a considerable labor force (UNESCO, 2012: 5).

The cultural and creative industries that play a vital role in the cultural economy are very dynamic. Traditionally, the linkage between cultural and creative endeavors and the economy has consisted of finding answers to questions on art and market failure (cultural economy) or seeking the justification of cultural regulations (Marco-Serrano, Rausell-Kosovo and Abeledo-Sanche, 2014: 82). However, today we concentrate on the role of media, communication, and culture as the "capitalist engine" in creating change and growth in the Schumpeterian sense (Cunningham, 2011: 48). In the 1990s, the annual growth of the cultural and creative sectors was more than double that of the services sector and four times that of the manufacturing sector in OECD countries (UNESCO Global Report, 2009). These industries accounted for over 7\% of the world's gross product in 2010 and $17.6 \%$ in the Middle East, $13.9 \%$ in Africa, 11.9\% in South America, and 9.7\% in Asia. It is one of the fastest growing sectors of the world economy, with growth of 6.9 percent in Oceania (Bandarin, Hosagrahar and Albernaz, 2011: 15). Power and Nielsen (2010) and Power (2011) state that the regions where the creative and cultural industries in Europe are concentrated have the highest benefit levels and claim a firm kinship between the scale of cultural industries and the wealth of regions in Europe. Using data at the regional level in Europe within the framework of structural equation modeling, Marco-Serrano et al. (2014) show that being a rich region is the reason for more employment in the creative and cultural sectors and that more people working in these sectors make these regions even richer. This shows us that the feedback effect is also in work to exacerbate the impact of the cultural production through increasing the revenue created in these sectors and creating job opportunities. Another similar study, based on data from 250 European regions, by Guel-Molina (2012) shows that creative industries play a key role in a region's wealth. Furthermore, the promotion of cultural and creative industries requires limited capital investment, and these sectors may have a direct effect on vulnerable groups, including women, as they have low barriers to entry.

Furthermore, cultural and creative industries take on new economic importance in the form of industrial districts. Moreover, they are made with the logic of industrial districts, making a path to economic development through the development of small and medium-sized houses that are highly integrated into the neighborhood and local community. The industrial district, founded on domestic culture, serves as a symbolic model of cultural areas. Cultural industry districts are defined as places for the production of unique products based upon creativity and intellectual property. The production in such industries includes the creation of several products. The cinematographic industry, the audiovisual sector, the vast field of industrial design and the production of works of art and crafts, museum services and ecological complexes are inspired by cultural links with local communities of origin. Here, creativity is expressed in culture, and culture is used to produce precious economic goods and services. This close connection between the social environment and its historic development is behind the main competitive advantages (Santagata, 2002: 11).

Investing in culture and creativity has also been an important way to stimulate the urban economy. Nowadays, many cities use cultural heritage, events and institutions related with culture to improve their image, promote urban development and attract investment as well as visitors (UNESCO, 2012: 4). The International Council on Monuments and Sites (ICOMOS), a key driver of urban development, also confirms that culture and cultural heritage bring diverse benefits to urban areas by improving economic success and sustainability. Cultural heritage/landscape plays a critical role in the realization of a humanist and the ecological paradigm for cities. The city's historical parks or squares in historical areas or public places adjacent to historical monuments offer meaningful and attractive opportunities for citizens to engage in urban culture and take part in public activities among several members of the community (Hosagrahar, Soule, Girard and Potts, 2016: 43). Museums, art galleries, performance theaters, and various cultural festivals create creative cities. From a cultural capital perspective, these cultural assets are the cultural capitals of the city (Throsby, 2010: 93). In addition, the cultural heritage of cities enhances the identity and sense of belonging of local communities and promotes social cohesion, social inclusion, and equity. Preserving cultural heritage and traditional settlements is a critical factor in economic and social development and poverty reduction, enhancing the livability and sustainability of urban areas and in the development of surrounding areas (Hosagrahar et al., 2016: 38).

These discussions indicate that the domestic contribution of cultural industries to economic activities is wellunderstood. However, the contribution of international trade of cultural goods to economic growth is not discovered in the economics literature. The voluminous empirical literature on the trade-growth relationship backs 
the positive and significant impact of international trade on growth and output (Singh, 2010, and references therein). Nevertheless, there is no empirical study on the relationship between international cultural trade and economic growth.

\section{DATA AND ECONOMETRIC METHODOLOGY}

\subsection{Data}

In setting out the relationship between international trade in cultural property and economic growth, we must first clarify what we mean by cultural property. Here, we adopt the classification by the 2009 UNESCO Framework for Cultural Statistics (FCS), which determines the structure of the world trade of cultural goods. The domains defined by FCS are:

- Domain A - Cultural and natural heritage: This domain consists of “Collections and collectors' pieces of zoological, botanical, mineralogical, anatomical, historical, archaeological, paleontological, ethnographic or numismatic interest" and "Antiques of an age exceeding one hundred years" items in customs statistics.

- Domain B - Performance and Celebration: This domain consists of recorded media and musical instruments.

- Domain C - Visual Arts and Crafts: This field covers visual arts products such as statuettes, sculptures or engravings; art crafts such as jewellery or fabric goods.

- Domain D - Books and press: This field consists of printed volumes, papers, magazines, and periodicals.

- Domain E - Audiovisual and interactive media: This domain includes video games and motion picture films.

- Domain F - Design and Creative Services: Architectural "Plans and Drawings" in customized statistics (Deloumeaux, 2016).

Using this categorization, we collect annual data on cultural trade balance (TB) and cultural trade volume (TV) in current prices expressed in million US dollars (USD). TB and TV series are obtained from the UNESCO Institute for Statistics (UIS).

To proxy economic growth, we utilize GDP per capita (GDP_PC) in the current USD series retrieved from the World Bank World Development Indicators. The data availability leaves us with a balanced set of 85 countries for which we have annual data between 2004-2017. Countries are also grouped into different income groups regarding the current World Bank classification.

\subsection{Econometric Methodology}

In this study, we conduct two separate analyses to examine the role international cultural trade plays in economic growth. First, we use the Pedroni cointegration test offered by Pedroni $(1999,2004)$ to examine whether international cultural trade (cultural trade balance and volume of cultural trade) and per capita GDP have a longterm cointegration relationship. Secondly, to estimate the effect of international cultural trade variables on GDP per capita, we use the random coefficients model put in place by Swamy (1970). The random coefficient model allows us to account for the potential heterogeneity between countries and we have individual coefficients on the impact of cultural trade variables on economic growth. The study thus has the advantage of assessing the relationship between trade in cultural products and economic growth in countries with different incomes.

The econometric specification of this study is as follows: Firstly, we determine the presence of cross-sectional dependency between countries. Then, we apply appropriate unit root test and determine the order of integration for each variable. In the third step, we used the cointegration test to assess if cultural trade and economic growth have a long-term cointegration relationship. Lastly, the random coefficient model gives the impact of cultural trade on economic activity in the sampled countries.

Before we look at the relationship between international cultural trade and GDP per capita, we must first determine the levels of integration of variables using a unit root analysis. Pedroni cointegration test requires series that are integrated of degree one. On the other hand, the random coefficient model also requires the detection of the degree of integration of variables to execute the regression model. However, the cross-sectional dependence from one country to the next determines whether the study should use first- and second-generation root tests. In this respect, the study first calls for a set of cross-sectional dependency tests. Then, the cross-dependency results determine what type of unit root test to use in the next step. 
We investigate the cointegration relationship between the pair of series. In these two analyses, we use the Pedroni cointegration test offered by Pedroni (1999, 2004). The Pedroni cointegration test displays seven statistics for testing cointegration among variables under the null of no cointegration (Pedroni, 1999; 2004). These statistics are grouped into two categories. The first category includes group-mean statistics, while the second category consists of the panel statistics. Since these test statistics are adjusted, they have a normal distribution with $\mathrm{N}(0,1)$. Pedroni (2004) argues that of these seven test statistics, group augmented Dickey-Fuller (ADF) and panel ADF statistics provide robust results when the time dimension is smaller than a hundred units $(T<100)$.

In the second analysis, we use Swamy (1970)'s random coefficient model. The parameter variation across units may go up due to various shocks in the economy, misspecification of the model, and the nonlinearities across the variables (Sarris, 1973). In this sense, the random coefficient model assumes that each of the cross-section coefficients is extracted from a distribution with a common mean and non-zero covariance matrix (Maddala, Trost, Li and Joutz, 1997). Thus, an observational-unit-specific parameter is estimated in this type of analysis.

\section{EMPIRICAL RESULTS}

As mentioned above, the study first utilizes the set of cross-sectional dependence tests. The results of these tests are shown in Table 1.

Table 1. Cross-Sectional Dependence Tests Results

\begin{tabular}{lllllllll}
\hline Variable & $\begin{array}{l}\text { Breusch- } \\
\text { Pagan LM }\end{array}$ & & $\begin{array}{l}\text { Pesaran } \\
\text { Scaled LM }\end{array}$ & $\begin{array}{l}\text { Bias- } \\
\text { Corrected } \\
\text { Scaled LM }\end{array}$ & \multicolumn{2}{c}{$\begin{array}{l}\text { Pesaran } \\
\text { CD }\end{array}$} \\
\hline TB & $10,311.610^{* * *}$ & 0.00 & $79.783^{* * *}$ & 0.00 & $76.514^{* * *}$ & 0.00 & $16.640^{* * *}$ & 0.00 \\
TV & $10,590.820^{* * *}$ & 0.00 & $83.088^{* * *}$ & 0.00 & $79.818^{* * *}$ & 0.00 & $47.772^{* * *}$ & 0.00 \\
GDP_PC & $41,678.140^{* * *}$ & 0.00 & $450.991^{* * *}$ & 0.00 & $447.722^{* * *}$ & 0.00 & $199.606^{* * *}$ & 0.00 \\
\hline
\end{tabular}

Note: $* * *$ denotes statistical significance at $1 \%$.

In these tests, we inspect the Lagrange Multiplier (LM) test of Breusch and Pagan (1980), Cross Sectionally Dependency Lagrange Multiplier (CDLM), and CD tests proposed by Pesaran (2004), and the adjusted LM test of Pesaran, Ullah, Yamagata (2008). Table 1 displays that in all series, the null of the cross-sectional independence is rejected. Therefore, these series are all have cross-sectional dependence in panel units. These results indicate that root tests of first-generation units may give biased results. Thus, second-generation unit root tests are more suitable for determining the level of integration between variables.

The presence of a cross-sectional dependence from one country to the next leads us to use the second-generation root unit test. At this moment, we use a cross-sectionally augmented Dickey-Fuller (CADF) test that is proposed by Pesaran (2007). The results of the unit root analysis are illustrated in Table 2.

Table 2. CIPS Test Results

\begin{tabular}{lcc}
\hline Variables & Constant & Constant \& Trend \\
\hline TB & -1.848 & -1.924 \\
TV & -1.320 & -1.462 \\
GDP_PC & -1.770 & -1.672 \\
$\Delta$ TB & $-2.189^{* * *}$ & $-4.052^{* * *}$ \\
$\Delta$ TV & -1.644 & $-2.786^{* * *}$ \\
$\Delta$ GDP_PC & $-2.371 * * *$ & $-2.925^{* * *}$ \\
\hline
\end{tabular}

Note: *,** and *** denote statistical significance at $10 \%, 5 \%$ and $1 \%$ respectively. For the constant model critical values for $1 \%, 5 \%$, and $10 \%$ are $-2.23,-2.09$, and -2.01 respectively. For constant and trend model critical values for $1 \%, 5 \%$, and $10 \%$ are $-2.77,-2.62$, and -2.54 respectively.

CADF test provides cross-sectionally augmented Im, Pesaran, and Shin (CIPS) statistics. CIPS statistics provide us the average value of the test statistics in panel members and used in the determination of the order of integration. Table 2 denotes that the null of nonstationarity cannot be rejected for all series in their level values. It looks that the null of nonstationarity can be turned down for the first difference value of the series and therefore demonstrates that these series are integrated of order one. Thus, we can conclude that these series are suitable in performing the cointegration test since all are integrated in order one. 
Afterward, we proceed to investigate the long-term cointegration relationship between cultural trade variables and per capita income in a panel of 85 countries. In this context the study performs Pedroni cointegration test between the set of pairs: (a) between TB and GDP_PC and (b) between TV and GDP_PC. Table 3 depicts the Pedroni cointegration test results between TB and GDP_PC.

Table 3. Pedroni Cointegration Test Results between TB and GDP_PC

\begin{tabular}{lcll}
\hline Test Stats. & Stats. & Test Stats. & Stats. \\
\hline Panel v & 1.794 & & \\
Panel rho & 0.629 & Group rho & 4.352 \\
Panel t & -0.3023 & Group t & 1.224 \\
Panel ADF & 3.344 & Group ADF & 2.273 \\
\hline
\end{tabular}

Note: Panel v statistics is a right-tailed test, while the remaining are left-tailed tests. Test statistics are for standardized normal distribution under $\mathrm{N}(0,1)$. Critical values are -1.96 , and 1.96 for $5 \%$ for left tail and right tail tests respectively.

Pedroni cointegration test provides seven test statistics to determine whether the variables have a long-term relationship. Table 3 shows that the seven statistics put forward by the Pedroni cointegration test are statistically insignificant. These results suggest that the lack of cointegration between the cultural trade balance and per capita GDP cannot be rejected. Thus, our findings exhibit no cointegration between trade balance and GDP per capita for the panel of 85 countries. Therefore, one can conclude that cultural trade balance, which is the difference between cultural exports and imports, and GDP per capita do not have a long-run relationship. In other words, these two series do not move together in the long run.

Table 4 reports whether the trade volume and the GDP per capita have a long-run relationship. Table 4 indicates that all seven statistics are statistically insignificant. Thus, we fail to reject the null of no cointegration relationship between international cultural trade volume and GDP per capita panel of 85 countries. The non-existence of such a linkage suggests that policies boosting the trade volume may not induce higher per capita growth.

Table 4. Pedroni Cointegration Test Results between TV and GDP_PC

\begin{tabular}{lclc}
\hline Test Stats. & Stats. & Test Stats. & Stats. \\
\hline Panel v & $3.593^{*}$ & & 7.253 \\
Panel rho & 2.848 & Group rho & 8.932 \\
Panel t & 5.091 & Group t & 12.110 \\
Panel ADF & 9.516 & Group ADF & \\
\hline
\end{tabular}

Note: Panel v statistics is a right-tailed test, while the remaining are left-tailed tests. Test statistics are for standardized normal distribution under $\mathrm{N}(0,1)$. Critical values are -1.96 , and 1.96 for $5 \%$ for left tail and right tail tests respectively. * represents significant coefficient.

Since the Pedroni cointegration test results do not provide a cointegration relationship in a panel of 85 countries, we cannot estimate the long-run regression coefficients. Instead, we employ the random coefficient model to see cross-sectional differences across the countries in terms of the relationship between cultural trade and the GDP per capita.

The following tables display the random coefficient model results in two sets of pairs. In the first model, we regress GDP per capita on the cultural trade balance, while in the second model, we regress GDP per capita on cultural trade volume. Besides, these 85 countries are also classified into four according to their GDP per capita levels. The results of the random coefficient model between cultural trade balance and GDP per capita for 85 countries and their income groups are tabulated in Table 5.

Table 5. Random Coefficient Results between Cultural Trade Balance and GDP per capita

\begin{tabular}{lccclccc}
\hline Country & Coeff. & Prob. & Code & Country & Coeff. & Prob. & Code \\
\hline Mozambique & 0.001 & 0.979 & 1 & South Africa & -0.38 & 0.626 & 3 \\
Madagascar & -0.086 & 0.364 & 1 & Sri Lanka & 1.212 & $0.034^{* *}$ & 3 \\
Malawi & -0.012 & 0.173 & 1 & Australia & -0.896 & 0.87 & 4 \\
Uganda & -0.005 & 0.84 & 1 & Austria & -0.611 & 0.862 & 4 \\
Bolivia & 0.266 & 0.829 & 2 & Belgium & -2.896 & 0.165 & 4 \\
Côte d'Ivoire & -2.229 & 0.654 & 2 & Canada & -0.209 & 0.617 & 4 \\
El Salvador & 0.573 & 0.222 & 2 & Chile & -0.577 & 0.917 & 4
\end{tabular}


Süleyman Demirel Üniversitesi Vizyoner Dergisi, Yıl: 2021, Cilt: 12, Sayı: 30, 381-392.

Süleyman Demirel University Visionary Journal, Year: 2021, Volume: 12, No: 30, 381-392.

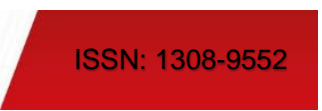

\begin{tabular}{|c|c|c|c|c|c|c|c|}
\hline Country & Coeff. & Prob. & Code & Country & Coeff. & Prob. & Code \\
\hline India & 0.297 & 0.853 & 2 & China,(Hong Kong, SAR) & -0.063 & 0.952 & 4 \\
\hline Morocco & -0.988 & 0.16 & 2 & Croatia & -8.308 & $0.087^{*}$ & 4 \\
\hline Senegal & 0.56 & $0.082^{*}$ & 2 & Cyprus & -8.217 & 0.12 & 4 \\
\hline Pakistan & -0.883 & 0.123 & 2 & Czechia & 0.445 & $0.015^{* *}$ & 4 \\
\hline Zimbabwe & -1.596 & 0.559 & 2 & Denmark & -10.776 & $0.048^{* *}$ & 4 \\
\hline Nicaragua & 0.001 & 0.993 & 2 & Estonia & -8.731 & 0.121 & 4 \\
\hline Tunisia & 0.187 & 0.902 & 2 & Finland & -3.165 & 0.23 & 4 \\
\hline Viet Nam & -0.005 & 0.501 & 2 & France & -5.231 & 0.294 & 4 \\
\hline Albania & -2.268 & 0.483 & 3 & Germany & -10.56 & $0.013^{* *}$ & 4 \\
\hline Algeria & 0.713 & 0.793 & 3 & Greece & 6.846 & 0.225 & 4 \\
\hline Argentina & -2.522 & 0.486 & 3 & Hungary & 0.378 & 0.921 & 4 \\
\hline Armenia & 3.683 & 0.364 & 3 & Iceland & -1.022 & 0.615 & 4 \\
\hline Azerbaijan & -4.594 & 0.409 & 3 & Ireland & -2.326 & 0.682 & 4 \\
\hline Belarus & -0.004 & 0.94 & 3 & Israel & 0.622 & 0.809 & 4 \\
\hline Bosnia and Herzegovina & -0.131 & 0.403 & 3 & Italy & -0.897 & 0.73 & 4 \\
\hline Brazil & -0.784 & 0.844 & 3 & Japan & -5.756 & 0.299 & 4 \\
\hline Bulgaria & -3.312 & 0.558 & 3 & Latvia & -5.254 & 0.326 & 4 \\
\hline China & 2.896 & 0.595 & 3 & Lithuania & -0.652 & 0.649 & 4 \\
\hline Colombia & -1.414 & 0.149 & 3 & Luxembourg & -0.926 & 0.775 & 4 \\
\hline Costa Rica & -5.618 & 0.322 & 3 & Netherlands & -2.972 & 0.562 & 4 \\
\hline Ecuador & 0.018 & $0.000^{* * * *}$ & 3 & Norway & 2 & $0.03^{* *}$ & 4 \\
\hline Fiji & -1.444 & 0.364 & 3 & Slovakia & -3.872 & 0.278 & 4 \\
\hline Guatemala & -0.206 & 0.549 & 3 & Sweden & -0.321 & 0.709 & 4 \\
\hline Jamaica & 1.777 & 0.165 & 3 & Uruguay & -0.042 & 0.358 & 4 \\
\hline Jordan & -0.123 & 0.444 & 3 & New Zealand & -0.454 & 0.919 & 4 \\
\hline Kazakhstan & -3.218 & $0.016^{* *}$ & 3 & Oman & -5.159 & 0.108 & 4 \\
\hline Peru & 0.514 & $0.085^{*}$ & 3 & Poland & -3.951 & $0.055^{*}$ & 4 \\
\hline Turkey & -4.752 & 0.392 & 3 & Portugal & 0.289 & 0.205 & 4 \\
\hline Lebanon & -0.939 & $0.05^{* *}$ & 3 & Republic of Korea & 0.019 & 0.943 & 4 \\
\hline Malaysia & -0.119 & 0.968 & 3 & Singapore & 0.388 & 0.844 & 4 \\
\hline Mauritius & 0.007 & 0.746 & 3 & Slovenia & -4.887 & $0.014^{* *}$ & 4 \\
\hline Namibia & -0.817 & 0.281 & 3 & Spain & -0.985 & 0.502 & 4 \\
\hline Paraguay & -5.483 & 0.325 & 3 & Switzerland & -0.1 & 0.853 & 4 \\
\hline Russian Federation & 2.111 & 0.653 & 3 & United Kingdom & -2.481 & 0.153 & 4 \\
\hline Mexico & -12.392 & $0.016^{* *}$ & 3 & USA & 0.258 & 0.239 & 4 \\
\hline Romania & -4.627 & 0.414 & 3 & & & & \\
\hline $\begin{array}{l}\text { Slope Homogeneity Results } \\
\text { Test of Parameter Constancy (Chi2) } \\
\text { Prob. Value }\end{array}$ & & & & $\begin{array}{c}2,780.05 \\
(0.000)\end{array}$ & & & \\
\hline
\end{tabular}

***** and ${ }^{*}$ represent $1 \%, 5 \%$ and $10 \%$ significance respectively.

Country Codes: 1: Low-Income, 2: Lower-Middle Income, 3: Upper Middle Income, 4: High Income

First of all, the parameter constancy results show us that the impact of trade balance is heterogenous across countries and therefore we can interpret the country-specific coefficients. This means that absolute changes in trade balance volume provide significantly different contributions to GDP per capita across countries.

However, Table 5 provides mixed results for individual countries. For the whole sample, only in 13 out of 85 countries, the trade balance seems to have a significant effect on GDP per capita across countries. However, the impact of the trade balance seems to be inconclusive since it does not provide a clear and concise pattern for the sample. Also, for the income groups, the results do not exhibit specific evidence that the trade balance is highly significant on GDP per capita for any income group. Therefore, our findings do not direct us to provide any significant impact of trade balance on economic growth regarding the income group of sample countries. 
Süleyman Demirel Üniversitesi Vizyoner Dergisi, Yıl: 2021, Cilt: 12, Sayı: 30, 381-392.

Süleyman Demirel University Visionary Journal, Year: 2021, Volume: 12, No: 30, 381-392.

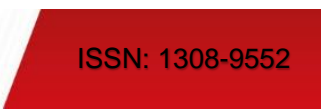

We construct a second model to analyze whether the cultural trade volume has a significant effect on GDP per capita across countries. In this model, we regress the cultural trade volume on GDP per capita, and the results are presented in Table 6.

Table 6. Random Coefficient Results between Cultural Trade Volume and GDP per capita

\begin{tabular}{|c|c|c|c|c|c|c|c|}
\hline Country & Coeff. & Prob. & Code & Country & Coeff. & Prob. & Code \\
\hline Madagascar & 1.497 & $0.000^{* * *}$ & 1 & South Africa & 1.112 & $0.007^{* * *}$ & 3 \\
\hline Malawi & 0.473 & 0.208 & 1 & Sri Lanka & 0.903 & 0.475 & 3 \\
\hline Mozambique & 0.078 & 0.834 & 1 & Turkey & 0.868 & $0.000^{* * * *}$ & 3 \\
\hline Uganda & 0.378 & 0.726 & 1 & Australia & -0.027 & 0.98 & 4 \\
\hline Bolivia & 1.206 & 0.252 & 2 & Austria & 0.383 & 0.297 & 4 \\
\hline Côte d'Ivoire & 0.904 & 0.716 & 2 & Belgium & 0.429 & 0.144 & 4 \\
\hline El Salvador & 1.922 & $0.046^{* *}$ & 2 & Canada & 0.657 & $0.082^{*}$ & 4 \\
\hline India & -0.001 & 0.769 & 2 & Chile & 6.591 & $0.070^{*}$ & 4 \\
\hline Morocco & -0.084 & 0.824 & 2 & China, Hong Kong, SAR & 0.265 & $0.007^{* * * *}$ & 4 \\
\hline Nicaragua & 0.761 & 0.64 & 2 & Croatia & 3.321 & 0.496 & 4 \\
\hline Pakistan & -0.025 & 0.645 & 2 & Cyprus & 9.072 & $0.067^{*}$ & 4 \\
\hline Senegal & 4.719 & $0.067^{*}$ & 2 & Czechia & -0.165 & $0.042^{* *}$ & 4 \\
\hline Tunisia & 2.71 & $0.006^{* * *}$ & 2 & Denmark & 0.974 & 0.17 & 4 \\
\hline Viet Nam & -0.009 & 0.72 & 2 & Estonia & 18.257 & $0.000^{* * * *}$ & 4 \\
\hline Zimbabwe & 0.413 & 0.858 & 2 & Finland & 9.655 & $0.000^{* * * *}$ & 4 \\
\hline Albania & -9.066 & $0.071^{*}$ & 3 & France & 0.28 & $0.007^{* * * *}$ & 4 \\
\hline Algeria & -0.069 & 0.614 & 3 & Germany & 0.142 & 0.22 & 4 \\
\hline Argentina & 9.241 & $0.000^{* * *}$ & 3 & Greece & 4.807 & $0.026^{* *}$ & 4 \\
\hline Armenia & 15.611 & $0.001^{* * *}$ & 3 & Hungary & 3.189 & $0.004^{* * * *}$ & 4 \\
\hline Azerbaijan & 4.247 & 0.266 & 3 & Iceland & 5.575 & $0.022^{* *}$ & 4 \\
\hline Belarus & 9.357 & $0.010^{* * *}$ & 3 & Ireland & -0.697 & 0.848 & 4 \\
\hline Bosnia and Herzegovina & 5.628 & 0.182 & 3 & Israel & 3.216 & 0.184 & 4 \\
\hline Brazil & 2.851 & $0.000^{* * *}$ & 3 & Italy & 0.421 & $0.009^{* * *}$ & 4 \\
\hline Bulgaria & 6.648 & $0.006^{* * *}$ & 3 & Japan & 0.296 & 0.113 & 4 \\
\hline China & -0.002 & 0.629 & 3 & Latvia & 8.868 & $0.06^{*}$ & 4 \\
\hline Colombia & 1.852 & $0.002^{* * *}$ & 3 & Lithuania & 12.848 & $0.004^{* * *}$ & 4 \\
\hline Costa Rica & 1.915 & 0.315 & 3 & Luxembourg & 9.709 & $0.058^{*}$ & 4 \\
\hline Ecuador & 4.684 & $0.061^{*}$ & 3 & Netherlands & 0.439 & $0.018^{* *}$ & 4 \\
\hline Fiji & 3.743 & 0.365 & 3 & New Zealand & -0.212 & 0.947 & 4 \\
\hline Guatemala & 0.154 & 0.825 & 3 & Norway & 13.462 & $0.003^{* * * *}$ & 4 \\
\hline Jamaica & 1.974 & $0.045^{* *}$ & 3 & Oman & -0.272 & 0.928 & 4 \\
\hline Jordan & 0.437 & 0.745 & 3 & Poland & -0.097 & 0.493 & 4 \\
\hline Kazakhstan & 1.989 & 0.145 & 3 & Portugal & 4.369 & $0.006^{* * *}$ & 4 \\
\hline Lebanon & 6.212 & $0.049^{* *}$ & 3 & Republic of Korea & 0.732 & $0.014^{* *}$ & 4 \\
\hline Malaysia & 0.243 & 0.64 & 3 & Singapore & 0.691 & $0.082^{*}$ & 4 \\
\hline Mauritius & -0.85 & 0.793 & 3 & Slovakia & 1.662 & 0.454 & 4 \\
\hline Mexico & 0.146 & 0.388 & 3 & Slovenia & 13.632 & $0.004^{* * *}$ & 4 \\
\hline Namibia & -0.342 & 0.947 & 3 & Spain & 0.698 & 0.152 & 4 \\
\hline Paraguay & 0.638 & 0.447 & 3 & Sweden & 1.611 & $0.082^{*}$ & 4 \\
\hline Peru & 5.043 & $0.000^{* * *}$ & 3 & Switzerland & 0.487 & $0.019^{* *}$ & 4 \\
\hline Romania & 3.983 & 0.243 & 3 & United Kingdom & 0.082 & $0.043^{* *}$ & 4 \\
\hline \multirow[t]{2}{*}{ Russian Federation } & 0.845 & $0.093^{*}$ & 3 & United States of America & 0.128 & $0.001^{* * *}$ & 4 \\
\hline & & & & Uruguay & -4.533 & 0.35 & 4 \\
\hline \multicolumn{4}{|c|}{$\begin{array}{l}\text { Slope Homogeneity Results } \\
\text { Test of Parameter Constancy (Chi2) } \\
\text { Prob. Value }\end{array}$} & $\begin{array}{c}3,369.77 \\
(0.000)\end{array}$ & & & \\
\hline
\end{tabular}

${ }^{* * * * * *}$ and ${ }^{*}$ represent $1 \%, 5 \%$ and $10 \%$ significance respectively.

Country Codes: 1: Low-Income, 2: Lower-Middle Income, 3: Upper Middle Income, 4: High Income 
The parameter constancy results, and the related statistics again denote that coefficients of trade volume variables are heterogenous across sample countries. In this context, the interpretation of the country-specific coefficients is meaningful in our model. Results between cultural trade balance and GDP per capita provide more clear and concise results. It seems that in 43 out of 85 countries, the cultural trade volume has a significant effect on GDP per capita. Also, the impact of cultural trade seems to significantly positive on GDP per capita. The impact of the cultural trade volume is significantly negative solely for two countries. In terms of income groups, again, our results are unclear on whether high- and low-income countries have significant benefits from cultural trade in increasing per capita economic growth.

Comparing with the model assessing the impact of cultural trade balance on per capita income one might infer that the trade volume provides relative much number of countries denoting a significantly positive relationship on economic activity measure.

\section{DISCUSSION AND CONCLUSION}

Cultural goods and services contribute to local economic growth in a number of ways. More specifically, cultural heritage, cultural and creative industries, tourism and infrastructure can be used as a strategic tool to generate income and thus stimulate economic growth. The literature on economic growth contains a great deal of research on the role of international trade in economic activity. Nevertheless, economic researchers or development agencies have largely neglected the economic value created by the use or consumption of cultural products. Even worse, they have ignored the potential of international trade of cultural products in fostering economic growth. Mostly non-economists have pointed to the contributing role of cultural industries and the international flow of cultural products to economic growth.

After the 2005 UNESCO Convention on the Protection and Promotion of the Diversity of Cultural Expressions called for developed countries to open their markets to developing countries' cultural goods and services, the international trade of cultural products took a new turn. The volume of international trade of cultural products with developing economies has increased since then. The digitalization and dematerialization of cultural products have also boosted the international flows of cultural goods and services. A relevant question, then, is whether prompted international trade of cultural products has any impact on economic growth. However, in the related empirical economics literature, the contribution of international flows in cultural products to economic growth has not been discovered. Therefore, the literature has more rooms for contribution to clarify the role of cultural trade in providing an economic growth in any country. The primary purpose of this study is to contribute to the literature in this way. Therefore, in this study, in order to fulfill this gap, we have explored the relationship between cultural trade and GDP per capita in 85 countries between 2004-2017. These countries are those that have a balanced set of observations in the study period. To this end, we have used international trade data prepared according to the classification by the 2009 UNESCO FCS. In a panel data specification, we used the Pedroni cointegration test (Pedroni, 1999, 2004) and estimated the Swamy random coefficient model (1970).

The empirical findings first denote that the impact of cultural trade variables are heterogenous across countries. Although the Pedroni cointegration test results do not indicate a long run cointegration relationship between cultural trade variables and income per capita, random coefficient model provides that the trade balance in cultural products does not have any impact on economic growth, while the volume of international trade of cultural products significantly and positively affects GDP per capita. Although there is no clear and concise difference regarding income group of sample countries, empirical results of the current study denote that there is a significant role of cultural trade activities on economic activity in much of these countries. It can be concluded that countries that stimulate cultural commercial activities and realize the importance of cultural products benefit from higher per capita incomes. It should also be inferred that rising per capita income could create new job opportunities for economies. These findings have implications for international trade policies for cultural products.

The main policy implication is that policymakers have no point to take protective measures against the imports of cultural goods or services. In this regard, the call of the 2005 UNESCO Convention on the Protection and Promotion of the Diversity of Cultural Expressions to developed economies to open their markets to developing countries' cultural goods and services is an appropriate proposal. Another implication for policymakers might be that promoting cultural industries and removing the barriers in such activities provide higher per capita income growth rates, increase related job opportunities in local economies. As such, decision makers should encourage investment to accelerate the production of cultural goods and services. 
The further research might be the one that aims at analyzing the role of cultural goods and services in promoting economic growth by disaggregating the related goods and services.

\section{DECLARATION OF THE AUTHORS}

Declaration of Contribution Rate: The first author is responsible for the literature review and data collection while the second author is responsible for the determination of the method, analysis and the reporting of the findings. The first author contributes $50 \%$ while the second author contributes $50 \%$.

Declaration of Support and Thanksgiving: No support is taken from any institution or organization.

Declaration of Conflict: There is no potential conflict of interest in the study.

\section{REFERENCES}

Bandarin, F., Hosagrahar, J. and Albernaz, F. S. (2011). Why development needs culture. Journal of Cultural Heritage Management and Sustainable Development, 1(1), 15-25.

Breusch, T. and Pagan, A. (1980). The Lagrange multiplier test and its applications to model specification in econometrics. The Review of Economic Studies, 47(1), 239-253.

Cunningham, S. D. (2011). Creative industries, its critics, and some answers. Ekonomiaz, 78(3), 47-60.

Deloumeaux, L. (2016). The Globalisation of Cultural Trade: A Shift in Consumption: International Flows of Cultural Goods and Services 2004-2013. (UNESCO-UIS 2016). Montreal, Canada: UNESCO Institute for Statistics.

De-Miguel-Molina, B., Hervas-Oliver, J.-L., Boix, R. and DeMiguel-Molina, M. (2012). The importance of creative industry agglomerations in explaining the wealth of European regions. European Planning Studies, 8(2012), 1263-1280.

Duxbury, N., Hosagrahar, J. and Pascual, J. (2016). Why must culture be at the heart of sustainable urban development?. Access address: http://www.agenda21culture.net/sites/default/files/files/documents/en/culture_sd_cities_web.pdf, (01.01.2020).

Hosagrahar, J., Soule, J., Girard, L. F. and Potts, A. (2016). Cultural heritage, the UN sustainable development. International Council on Monuments and Sites, 16(1), 37-54.

Maddala, G. S., Trost, R. P., Li, H. and Joutz, F. (1997). Estimation of short-run and long-run elasticities of energy demand from panel data using shrinkage estimators. Journal of Business and Economic Statistics, 15(1), 90-100.

Marco-Serrano, F., Rausell-Koster, P. and Abeledo-Sanchis, R. (2014). Economic development and the creative industries: a tale of causality. Creative Industries Journal, 7(2), 81-91.

Pedroni, P. (1999). Critical values for cointegration tests in heterogeneous panels with multiple regressors. Oxford Bulletin of Economics and Statistics, 61(1), 653-670.

Pedroni, P. (2001). Purchasing power parity tests in cointegrated panels. Review of Economics and Statistics, 83(4), 727-731.

Pedroni, P. (2004). Panel cointegration: asymptotic and finite sample properties of pooled time series tests with an application to the PPP hypothesis. Econometric Theory, 20(03), 597-625.

Pesaran, M. (2004). General Diagnostic Tests for Cross Section Dependence in Panels. (CESifo Working Paper Series 1229). Munich: CESifo Group.

Pesaran, M. (2007). A simple panel unit root test in the presence of cross-section dependence. Journal of Applied Econometrics, 22(2), 265-312.

Pesaran, M.H., Ullah, A. and Yamagata, T. (2008). A bias-adjusted LM test of error cross-section independence. Econometrics Journal, 11(1), 105-127. 
Power, D. (2011). Priority sector report: Creative and cultural industries. (Europa Innova Paper No:16). Belgium: European Commission.

Power, D. and Nielsen, T. (2010). Priority sector report: Creative and cultural industries. (Europa Innova Paper No:16). Belgium: European Commission.

Riofrio, M.D. (2014). UNESCO's concept of culture as a driver of sustainable development. Access address: https://www.academia.edu/27749131/UNESCOs_concept_of_Culture_as_a_Driver_of_Sustainable_De velopment, (12.09.2020).

Santagata, W. (2002). Cultural districts, property rights and sustainable economic growth. International Journal of Urban and Regional Research, 26(1), 9-23.

Singh, T. (2010). Does international trade cause economic growth? A survey. World Economy, 33(11), 1517-1564.

Swamy, P. A. (1970). Efficient inference in a random coefficient regression model. Econometrica, 38(2), 311-323.

Throsby, D. (2010). The Economics of Cultural Policy. Cambridge: Cambridge University Press.

UNESCO (2015). Reshaping Cultural Policies: A decade promoting the diversity of cultural expressions for development. (2005 Convention Global Report). Paris: UNESCO.

UNESCO World Report. (2009). Investing in Cultural Diversity and Intercultural Dialogue. UNESCO Publishing.

UNESCO. (2012). Culture: a driver and an enabler of sustainable development. Thematic think piece. Access address: https://www.un.org/millenniumgoals/pdf/Think\%20Pieces/2_culture.pdf, (08.06.2020).

United Nations (2011). Resolution adopted by the General Assembly on 20 December 2010: Culture and development. (A/RES/65/166). United Nations. 